\title{
ПОРІВНЯЛЬНА ОЦІНКА ВЕЛИЧИНИ АНТИАПОПТОТИЧНОГО ЕФЕКТУ СЕРЕД МОДУЛЯТОРІВ АКТИВНОСТІ NМDА-РЕЦЕПТОРІВ В УМОВАХ МОДЕЛЬНОЇ ПЕРЕХІДНОЇ ІШЕМІЇ-РЕПЕРФУЗІЇ ОКА ЗА ДАНИМИ ПРОТОКОВО-ЦИТОМЕТРИЧНОГО АНАЛІЗУ
}

\author{
๑В. Л. Повх ${ }^{1}$, М. А. Ходаківський², О. А. Ходаківський' \\ Вінницький національний медичний університет імені М. І. Пирогова ${ }^{1}$ \\ Військово-медичний центр Центрального регіону Військово-повітряних сил України, Вінниця²
}

\begin{abstract}
РЕЗЮМЕ. Модельна 60 хв ішемія-реперфузія ока у щурів супроводжується активацією апоптотичних процесів в сітківці, про що достеменно свідчить збільшення в середньому в 20,22 раза пулу клітин, які перебувають у фазіSUBG0G1, тобто мають ознаки фрагментації ядерної ДНК, що анонсує апоптоз. Однократна внутрішньовенна інфузія в лікувальному режимі через 30 хв після накладання лігатур розчинів амантадину або магнію сульфату, дозами 5 та 250 мг/кг відповідно, а також мемантин перорально з розрахунку 20 мг/кг, сприяють зменшенню відносної кількості ретиноцитів, які перебувають фазі SUB-G0G1 клітинного циклу, проявляючи тим самим антиапоптотичну дію. За спроможністю в умовах даної патології знижувати процес фрагментації ядерної ДНК, застосування розчину амантадину сульфату вірогідно переважає терапію розчином магнію сульфату або мемантином в середньому на 24,1 та 52,0\% відповідно.
\end{abstract}

КЛЮчОВІ СЛОВА: апоптоз, амантадину сульфат, магнію сульфат, мемантин.

Вступ. За даними наших попередніх досліджень [1-6], присвячених порівняльній оцінці впливу деяких блокаторів NMDA-рецепторів на нейропроліферативні та деструктивно-дегенеративні явища в сітківці на тлі модельної ішемії-реперфузії або контузії ока, найсуттєвішу дію на окреслені процеси має розчин амантадину сульфату та мемантин. Після реперфузії вогнище деструктивно-дегенеративних змін в сітківці $є$ неоднорідним та гетерогенним, формується за рахунок як некротичних, так і апоптотичних процесів, які чітко розмежувати неможливо. Використовуючи біохімічні (визначення активності та моніторинг змін титрів нейромаркерів в крові) та цитологічні методики можна встановити інтенсивність цих змін, а також внесок кожного типу смерті в загальну картину ураження зорового аналізатора. За визначенням Номенклатурного комітету по клітинній смерті, (NCCD) апоптоз - це впорядкований, генетично детермінований процес елімінації пошкоджених клітин, морфологічний критерій незворотності якого визначається фрагментацією ядерної ДНК [7]. Про питому вагу в окреслених патоморфологічних змінах сітківки у постреперфузійний період власне апоптозу можна судити саме за зростанням кількості клітин, що перебувають у фазі SUB-G0G1, тобто мають ознаки фрагментації ДНК. Це і $\epsilon$ апоптотичним маркером.

Мета. У гострий період постреперфузійної ретинальної ішемії використовуючи протоковий цитометричний аналіз дослідити активацію апоптотичних процесів в клітинах сітківки за наявною фрагментованою ядерною ДНК та оцінити ефективність блокаторів NMDA-рецепторів за допомогою цього критерію.

Матеріал і методи дослідження. Оцінку апоптозомодулювальних властивостей досліджуваних блокаторів NMDA-рецепторів проведено на
66 щурах-самцях лінії Вістар масою 160-190 г. Усі тварини знаходились у віварії Вінницького національного медичного університету (ВНМУ) імені М. І. Пирогова на стандартному водно-харчовому раціоні при природному освітленні та вільному доступі до води та корму. Під час роботи з лабораторними тваринами дотримувались методичних рекомендацій Державного фармакологічного центру Міністерства охорони здоров'я (МО3) України і вимог біоетики згідно з Національними «Загальними етичними принципами експериментів на тваринах» (2001), що відповідають положенням «Європейської конвенції про захист хребетних тварин, які використовуються для експериментальних та інших наукових цілей». Дотримання біоетичних норм засвідчено комісією з біоетики ВНМУ імені М. І. Пирогова (висновок № 2 від 05.02.2015).

Роботу виконано відповідно до плану науково-дослідних робіт ВНМУ імені М. І. Пирогова МO3 України у рамках тем «Пошук та розробка нових шляхів фармакологічної корекції порушень при ішемічному ушкодженні мозку та серця в експерименті» (номер держреєстрації 0112U0021939) та «Доклінічна оцінка перспективних органопротекторів» (номер держреєстрації 00115U007126).

Ішемічне ураження сітківки моделювали в умовах перехідної ішемії на моделі ішемії-реперфузії (IP) ока. IP досягали шляхом накладання ретробульбарної лігатури на ліве око щурів терміном 1 год. Через 60 хв після ішемії лігатури обережно розпускали і знімали. Кровобіг швидко відновлювався самостійно. Стан очного дна контролювали за допомогою прямої офтальмоскопії (попередньо наносили на рогівку гель) через покривне скло, що використовується для виготовлення гістологічних препаратів. 
Огляди літератури, оригінальні дослідження, погляд на проблему

В якості предмета досліджень у ролі модуляторів активності NMDA-рецепторів ми обрали мемантин («Мема» Актавіс-Україна, Україна) та розчини амантадину («ПК-MЕРЦ», Merz Pharmaceuticals, Швейцарія) і магнію сульфату («Магнію сульфатДарниця», Дарниця, Україна).

Обрані лікарські засоби вводили однократно в лікувальному режимі через 30 хв після накладання ретробульбарної лігатури у дозах, які за даними наших попередніх скринінгових досліджень виявились умовно-ефективними за максимальним нейроретинопротективним ефектом на при аналогічному ураженні зорового аналізатора. Для мемантину ця доза складає 20 мг/кг внутрішньошлунково (в/ш), а для розчинів амантадину i магнію сульфату відповідно 5 та 250 мг/кг внутрішньовенно (в/в) [4].

Для в/ш введення мемантину через металічний орогастральний зонд (діаметр $22 \mathrm{G}$ ), готували його суспензію із твіном-80, розраховуючи концентрацію таким чином, щоб їі загальний об'єм, який уводився в/ш, становив 2 мл/кг. Розчини амантадину і магнію сульфату вводили в/в у попередньо катетеризовану (катетер, ERG 22 G, Польща) стегнову вену за допомогою інфузоматної системи упродовж перших 2 год з моменту накладання лігатури за методикою, розробленою д-р мед. наук О. А. Ходаківським [3]. Група контрольної патології (тварини з IP без цитопротекторної терапії) отримувала 0,9\% розчин $\mathrm{NaCl}$ із розрахунку 2 мл/кг в/в. Групі псевдооперованих щурів накладали ретробульбарні лігатури без наступного їх затягування. Будь-які травматичні маніпуляції та евтаназію тварин шляхом декапітації виконували в умовах пропофолового наркозу (60 мг/кг внутрішньоочеревинно) («Fresenius Kabi», Австрія) [4].

Для проведення цитометричних досліджень сітківки [1], через 24 год після моделювання патології очі швидко підлягали енуклеації з подальшою промивкою холодним розчином $0,9 \% \mathrm{NaCl}$ $\left(+4^{\circ} \mathrm{C}-+8^{\circ} \mathrm{C}\right)$. Очні яблука щурів позбавляли залишок кон'юнктиви та м'язів і за допомогою мікрохірургічного інструментарію видаляли передній відділ ока і кришталик. Після 4 надрізів залишки очного яблука розправляли таким чином, щоб очне дно було доступне огляду, помічали і видаляли ділянки сітківки. Вміст ДНК в ядрах клітин сітківки щурів визначали методом протокової цитометрії на багатофункціональному науково-дослідному протоковому цитометрі "Рагtec PAS" (Partec, Німеччина). Суспензії ядер з клітин сітківки отримували за допомогою наборів для дослідження ядерної ДНК, відповідно, CyStain DNA Step 1 та CyStain DNA Step 2 (Partec, Німеччина) до складу яких входить діамідинофеніліндол (DAPI). У процесі виготовлення нуклеарних суспензій використовували одноразові фільтри CellTrics 50 мкм (Partec, Німеччина). Для збудження флуоресценції DAPI застосовували ультрафіолетове випромінювання. Якість промаркованих ядерних суспензій перевіряли за допомогою флуоресцентного мікроскопа ЛЮМАМ Р-8 (ЛОМО, СРСР) (ультрафіолетове збудження), цифрової камери TSView (TUCSEN, Китай) з роздільною здатністю матриці 8 Мп. Із кожного зразка нуклеарної суспензії аналізували 20 тис. о6'єКтів, що містять ДНК. Визначення фрагментації ДНК (апоптоз) виконано шляхом виділення SUB-G0G1 ділянки на ДНКгістограмах RN1 перед піком G0G1, яка вказує на ядра клітин з вмістом ДНК < 2 с.

Аналіз ДНК гістограм виконували засобами програмного забезпечення проточного цитометра FloMax. Використовували параметричний критерій $t$ Стьюдента у випадках нормального розподілу варіаційного ряду, непараметричний критерій W Уайта - за його відсутності (Partec, Hiмеччина). Відмінності вважали статистично значущими при $\mathrm{p}<0,05$.

Результати й обговорення. Проведене дослідження показало, що у гострий постреперфузійний період в сітківці щурів групи контрольної патології прослідковується апоптотична активність, про що достеменно свідчило збільшення в середньому в 20,22 раза пулу клітин, які перебували у фазі SUB-G0G1, тобто мали ознаки фрагментації ядерної ДНК, що анонсує апоптоз (табл. 1) p<0,05.

Таблиця 1. Вплив розчинів амантадину і магнію сульфату та мемантину при їх нарізному введенні на відносну кількість клітин, що перебувають у фазі SUBG0G1 із фрагментованою ядерною ДНК (апоптоз) до їх загальної кількості у суспензії сітківки кролів на 24 год терапії контузії ока (M $\pm \mathrm{m}, \mathrm{n}=7)$

\begin{tabular}{|l|c|}
\hline \multicolumn{1}{|c|}{ Умови досліду } & $\begin{array}{c}\text { Відносна } \\
\text { кількість клітин } \\
\text { (у \%), 3 фрагмен- } \\
\text { тацією ДнК } \\
\text { (апоптоз) }\end{array}$ \\
\hline Псевдооперовані щурі & $0,49 \pm 0,06$ \\
\hline $\begin{array}{l}\text { IP + 0,9\% розчин NaCl (контрольна } \\
\text { патологія) }\end{array}$ & $9,91 \pm 1,44^{*}$ \\
\hline IP + амантадину сульфат, 5 мг/кг в/в & $2,93 \pm 0,14^{* \# \wedge а ~}$ \\
\hline IP + магнію сульфат, 250 мг/кг в/в & $3,86 \pm 0,43^{* \# \wedge ~}$ \\
\hline IP + мемантин, 20 мг/кг в/ш & $6,11 \pm 0,61^{* \#}$ \\
\hline
\end{tabular}

Примітки:

1. IP - ішемія-реперфузія; в/в - внутрішньовенно,

в/ш-внутрішньошлунково;

2. * - $p<0,05$ відносно інтактних тварин;

3. \# - p<0,05 відносно контрольної патології;

4. ^ - $p<0,05$ відносно мемантину;

5. $a-p<0,05$ відносно магнію сульфату 
При нарізному введенні розчинів амантадину або магнію сульфату та мемантину, взятих терапевтично-ефективними дозами відповідно 5 і 250 мг/кг в/в та $20 \mathrm{мг/кг} \mathrm{в/ш} \mathrm{відбувались} \mathrm{кількісно-якісні}$ зміни у співвідношенні клітин у суспензії, отриманій із сітківки щурів, які перебувають на різних фазах клітинного циклу, в тому числі і фазі SUBG0G1, яка віддзеркалює процес фрагментації ДНК і маркує власне апоптоз. Всі досліджувані блокатори NMDA-рецепторів у застосованих дозах сприяли зменшенню відносної кількості ретиноцитів, які перебувають у фазі SUB-G0G1 клітинного циклу, однак ступінь зниження даного показника у різних препаратів був виражений по-різному.

Реалізація найпотужнішого антиапоптотичного ефекту на клітини сітківки мала місце на тлі застосування розчину амантадину сульфату дозою 5 мг/кг. Його в/в введення за допомогою інфузоматної системи супроводжувалось вірогідним, відносно групи контрольної патології, зменшенням питомої ваги клітин з ознаками фрагментації ДНК в середньому в 3,38 раза. Разом із цим, однократне застосування розчину магнію сульфату (250 мг/ кг) або мемантину перорально дозою 20 мг/кг призводило до зменшення відсотка клітин, які перебувають у фазі SUB-G0G1 клітинного циклу, відносно цього ж показника групи контрольної патології у середньому в 2,57 та 1,62 раза відповідно (табл. 1) $p<0,05$. При цьому застосування розчину магнію сульфату виявилось ефективнішим за мемантин в середньому в 1,32 раза, однак обидва вірогідно поступаються антиапоптотичному ефекту амантадину сульфату в середньому на 24,1 та 52,0 \% відповідно. Таким чином, проведене дослідження антиапоптотичних властивостей модуляторів активності NMDA-рецепторів, а саме мемантину i розчинів амантадину та магнію сульфату при ішемічному ураженні ока за ступенем деескалації числа клітин, ядерна ДНК яких перебуває в процесі фрагментації (деструкції), дозволило виявити препарат-лідер для подальшої поглибленої оцінки його захисних ефектів на сітківку. Цим препаратом $\epsilon$ розчин амантадину сульфату умовно-ефективною дозою 5 мг/кг в/в, який забезпечує максимальне, порівняно із іншими лікарськими засобами, зменшення відсотка клітин, які перебувають у фазі SUB-G0G1 клітинного циклу. За антиапоптотичною активністю досліджувані препарати можна розмістити в наступній послідовності: амантадину сульфат (5 мг/кг в/в) > магнію сульфат (250 мг/Кг В/в) > мемантин (20 мг/кг в/ш).

Висновки. 1. 60 хв IP ока у щурів супроводжується активацією апоптотичних процесів в сітківці, про що достеменно свідчить збільшення в середньому в 20,22 раза пулу клітин, які перебувають у фазі SUB-G0G1, тобто мають ознаки фрагментації ядерної ДНК, що анонсує апоптоз.

2. Амантадину сульфат (5 мг/кг в/в), магнію сульфат (250 мг/кг в/в) та мемантин (20 мг/кг в/ш) однократно в лікувальному режимі через 30 хв після накладання лігатур сприяють зменшенню відносної кількості ретиноцитів, які перебувають фазі SUB-G0G1 клітинного циклу, проявляючи тим самим антиапоптотичну дію.

3. За спроможністю в умовах даної патології знижувати процес фрагментації ядерної ДНК, застосування розчину амантадину сульфату вірогідно переважає терапію розчином магнію сульфату або мемантином в середньому на 24,1 та 52,0 \% відповідно. За антиапоптотичним ефектом досліджувані препарати можна розмістити в наступній послідовності: амантадину сульфат (5 мг/Кг в/в) > магнію сульфат (250 мг/кг в/в) > мемантин (20 мг/кг в/ш).

Перспективи подальших досліджень. Досліджувані блокатори активності NMDA-рецепторів $\epsilon$ перспективними для застосування за новим призначенням в якості нейроретинопротекторних препаратів, що потребує більш ґрунтовної доклінічної оцінки.

\section{ЛІТЕРАТУРА}

1. Використання нейромаркерів (білок $S$ 100) та методу протокової цитометрії для порівняльної оцінки впливу блокаторів NMDA-рецепторів на нейропроліферативні процеси в сітківці та зоровому нерві в умовах модельної ішемії-репефузії ока / І. Л. Черешнюк, В. Л. Повх, Г.В. Загорій, О. А. Ходаківський // Світ медицини та біології. - 2016. - № 2 (56). - С. 159-164.

2. Пат. на корисну модель № 104387 Україна МПК А61K 31/13 A61P 27/06. Застосування фармацевтичної композиції, що містить амантадин або його фармацевтично прийнятні солі для лікування захворювань зорового аналізатора / Г. В. Загорій, І. Л. Черешнюк ; замовник і патентовласник Г. В. Загорій. - № ч 201507455 ; заявл. 24.07.15; обубл. 25.01.16, Бюл. № 2, 2016 р.
3. Пат. на корисну модель № 109424 Україна МПК А61K 31/00 А61P 27/02 Застосування цитопротекторів, вибраних з ряду цитиколіну, мелатоніну, мексидолу, корвітину, тіотриазоліну та розчину сульфату магнію, як нейроретинопротекторів / І Л. Черешнюк, В. Л. Повх, К. М. Комнацька, О. А. Ходаківський ; замовник і патентовласник I Л. Черешнюк, В. Л. Повх, К. М. Комнацька, О. А. Ходаківський. - № ч 201601703 ; заявл. 23.02.16; опубл. 25.08.16, Бюл. № 16, 2016 р.

4. Повх В. Л. Нейроретинопротекторні властивості модуляторів активності NMDA-рецепторів при ішемічному ураженні ока (експериментальне досліджнення) / В. Л. Повх // Вісник морфології. - 2016. Т. 22, № 1. C. 53-57. 
Огляди літератури, оригінальні дослідження, погляд на проблему

5. Цереброваскулярные эффекты блокаторов

нюк, В. Л. Повх, Г. В.Загорий , О. В. Ходаковская // Врачаспирант. - 2016. - Т. 74, №1, 2. - С. 295-303.

6. Classification of cell death: recommendations NMDA-рецепторов и мексидола на фоне аллоксанового таболических процессов в сетчатке монгольских песчанок в острый постперфузионный период / И. Л. Черешof the Nomenclature Committee on Cell Death 2009 / G. Kroemer, L. Galluzzi, P. Vandenabeele [et al.] // Cell Death Differ. - 2009. Vol. 16, № 1. - P. 3-11.

\title{
COMPARATIVE EVALUATION OF VALUES OF ANTI-APOPTOTIC EFFECTS OF SOME MODULATORS OF THE ACTIVITY OF NMDA-RECEPTORS: MEMANTINE, AMANTADINE OR MAGNESIUM SULFATE IN THE MODEL IN TRANSITION ISCHEMIA REPERFUSION EYES BY FLOW-CYTOMETRIC ANALYSIS
}

\author{
@V. L. Povkh', M. A. Khodakivskyi², A. A. Khodakovskyi ${ }^{1}$ \\ M. Pyrohov Vinnytsia National Medical University \\ Military Medical Clinic Center of the Central Region of the Air Forces of Ukraine, Vinnytsia ${ }^{2}$
}

SUMMARY. Experimental ischaemia-reperfusion in rat eyes, within 60 minutes, accompanied by activation of apoptotic processes in the retina, as evidenced by the increase in 20.22 times the number of cells that are in phase SUBG0G1, i.e. have symptoms of nuclear DNA fragmentation. This indicates an apoptosis. A single intravenous infusion of solutions of magnesium sulphate or amantadine in doses of 5 and $250 \mathrm{mg} / \mathrm{kg}$, respectively, after $30 \mathrm{~min}$. after ligation, as well as memantine intragastrically $20 \mathrm{mg} / \mathrm{kg}$, contribute to reduce the number of retinal cells, which are phase SUB-G0G1 cell cycle, thereby exhibiting anti-apoptotic effects on the retina. Under the conditions of this disease in their ability to reduce the process of nuclear DNA fragmentation, amantadine sulfate solution gives significantly better effect (on average, 24.1 and $52.0 \%$ ) compared to treatment with a solution of magnesium sulfate or memantine.

KEY WORDS: apoptosis, amantadine sulfate, magnesium sulfate, memantine. 